\title{
The Flora of Krakatau
}

$\mathrm{T}$ HE eruption of Krakatau, from May 20 to the end of August 1883, which killed the vegetation of the three islands of the Krakatau group and destroyed some two thirds of the island of Krakatau itself, was perhaps the most important volcanic outburst, from the point of view of the biologist, that has occurred in historic times. Its biological importance is, of course, due to the fact that Krakatau is now one of a group of four (formerly three) islands in the middle of the Sunda Strait, Krakatau itself being $40 \mathrm{~km}$. distant from the nearest point of west Java, and the same distance from the nearest point, Varkenshoek, of south-eastern Sumatra. The nearest island to the group is the volcanic Sebesy Island, some $13 \mathrm{~km}$. to the north, where the vegetation was not wholly destroyed. If, as has generally been accepted, the whole of the regetation of the Krakatau islands was destroyed, then the study of the gradual reeolonization recently published by Dr. W. M. Docters van Leeuwen is of unique interest and importance. Krakatau's historic eruption, however, is only one of a series each of which, could it have been studied, would have afforded invaluable information as to methods of plant distribution. From the geological evidence, there was originally a single volcanic island in the Straits about $2,000 \mathrm{~m}$. high. This was destroyed, and the three main remaining portions are represented by Krakatau, Verlaten and Lang Islands, surrounding a deep circular sea basin. This eruption was followed by another violent one, and later, by the fusion of the two volcanoes Perbuatan and Danan, the historic island of Rakata or Krakatau, $9 \mathrm{~km}$. long and $5 \mathrm{~km}$. broad, was formed, two thirds of which were erupted and dispersed in 1883 . Recently Anak Krakatau has been erupted.

Prof. Treub of Buitenzorg, it will be remembered, was the first botanist to visit Krakatau after the eruption in 1883 . The earliest visitors to the island were Verbeek, two months, and Cotteau, the Frenchman, nine months after the eruption. Neither record the presence of any living plants, and Cotteau expressly states that he could not discern any vegetation on the island. It was the classic visit of Treub, nearly three years after the eruption, which focused attention on the problem of its recolonization, when he pointed out that the first colonizers of the volcanic ash and cinders were the blue-green Algæ, which formed a hygroscopic layer in which fern spores could germinate, and that under the conditions obtaining in a volcanic island such as Krakatau, ferns would necessarily precede the phanerogams. Of the plants recorded by Treub 
has marshalled all the facts and discussed fully the evidence which has been produced for and against the total destruction of the vegetation of Krakatau by the eruption of 1883 with judicial fairness*.

The circumstances, unfortunately, do not permit of an absolute 'yes' or 'no', since three years elapsed before the fairly full investigation of the island by Treub was made, and even then owing to the extreme difficulties in getting up the deep fissures and among the waste of volcanic ejecta, it was possible to examine only a relatively small portion of the island. Verbeek's statement, however (see p. 18), with reference to his visit to Krakatau in October 1883, that the ground was then so hot that the coolies with their bare feet

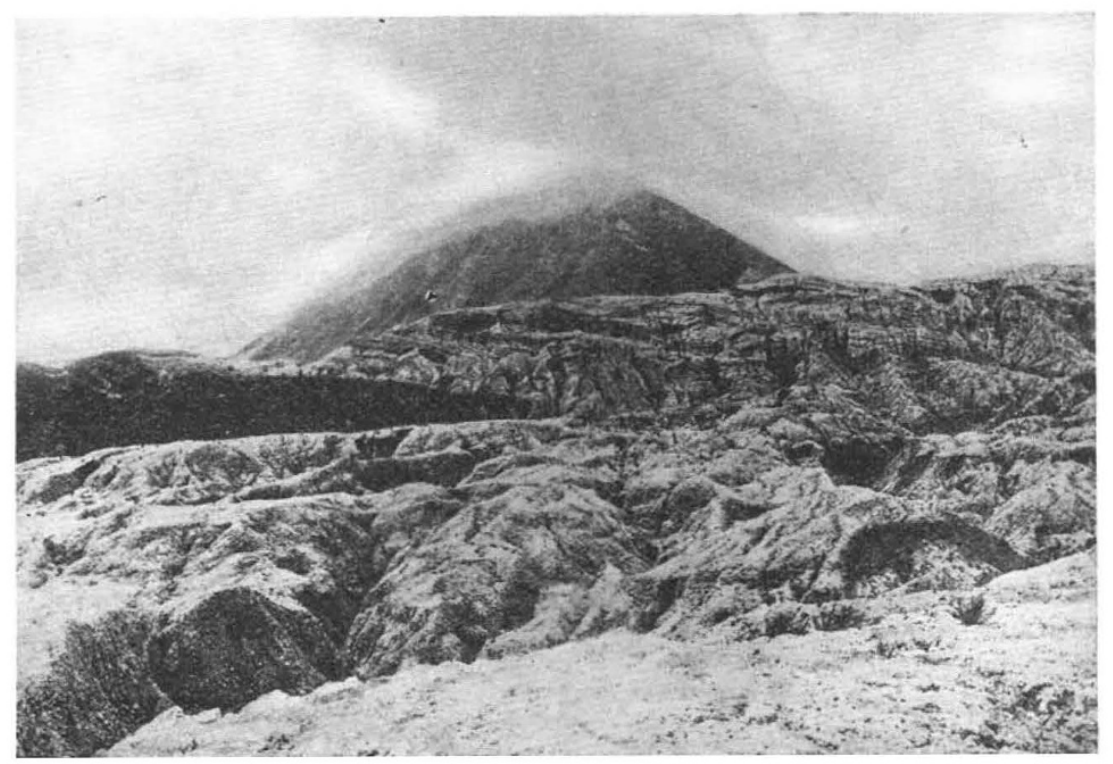

Fig. 2.

West side of Zwarte Hoek, June 20, 1886. Phato by H. Busenbender.

could not stand still and that steam was issuing from the bottom of the gaps cut out by the rain, makes it seem highly probable that all plant life, even that of seeds buried under the hot ashes and pumice, must have been destroyed. Verbeek concludes his letter to Docters van Leeuwen with praiseworthy caution: "I believe," he writes, "that this question can never be settled with absolute certainty, though I, myself, am inclined to assume that everything was dead".

Before the eruption, the islands were covered with dense tropical vegetation up to the top of Mount Rakata on Krakatau, and after the eruption there was nothing living to be seen, owing to the thick covering of ashes and pumice and the

* Krakatau, 1883-1933. By W. M. Docters van Leeuwen. A : Botany, (Annales du Jardin Botanique de Buitenzorg, Vol. 46-47.) Pp. xii $+506+37$ plates. (Leiden: E. J. Brill, 1936.) By the courtes
of the publishers, several of the illustrations are here reproduced. destructive effect of the hot gases, steam, etc. From the charred wood exposed by the washing away of the thick ash deposits, it seems clear that nothing in the way of stems or rhizomes could have survived. Buried seeds might have escaped destruction, had they been quickly exposed again by landslides or erosion, but the evidence for survival is very slight.

After all, Treub found only fifteen species of flowering plants three years after the eruption, and even if a few of these had grown from seeds which survived the eruption, their number is negligible compared with the 219 species which were recorded in 1934, all of which must have been brought to the islands by ocean currents, winds, birds or man.

Until the year 1908, no one appears to have questioned Treub's presumption of the complete sterilization of Krakatau. Penzig, who visited the island in 1897, Ernst in 1906 and Backer (on his first visit) in 1908, were all equally convinced.

The late Dr. J. P. Lotsy, writing in 1908, appears to have been the first to ques. tion the total destruction of the vegetation, on account of the finding of a large plant of Cycas Rumphii by Valeton in 1905, twentytwo years after the eruption! Based on the analogy of the growth of cycads in general, the objection might be a weighty one, but Dr. Docters van Leeuwen, on $p$. 346 in his detailed account of this plant, records how rapid is the growth of this species when young, and has shown by his own experiments that a plant of this Cycas can grow from seed to a height of more than 1 metre in the space of five years.

Other dissentient views are fully discussed and as fully rejected: it was not until the year 1929 that any serious challenge to the generally accepted opinion was brought forward. We have therefore to thank Mr. Backer (whose work was reviewed in NATURE, 125, 627; 1930), since it is not only owing to his expressed disbelief in the sterilization of Krakatau, but also on account of the aspersions he has cast on the work of Treub and the veracity and competence of previous investigators, including particularly Dr. Docters van Leeuwen, that we owe this volume, which will be the classic work of reference on the subject 
for all time and a vindication of Treub's fine pioneer investigations.

It is unnecessary here to go over again the various points raised by Backer, but it is good reading to follow Dr. Docters van Leeuwen's judicious handling of Backer's assumptions, some of which would have been quite reasonable had they had a shadow of evidence for their support.

Dr. Docters van Leeuwen has devoted a chapter (iv) of thirty pages to a review of the recolonization of other territories all over the world, and it present plant covering of the islands must consist wholly of immigrants.

The author devotes eight extensive chapters to the visits of the various botanists to the islands between 1884 and 1932, one being concerned with the stay of J. Händl on Krakatau, from 1916 until 1921, and the fate of any plants he and his workpeople may have introduced. He then gives a complete list of the flora of the island and records the different dates when the various species-now numbering $271-$ were first observed. These are

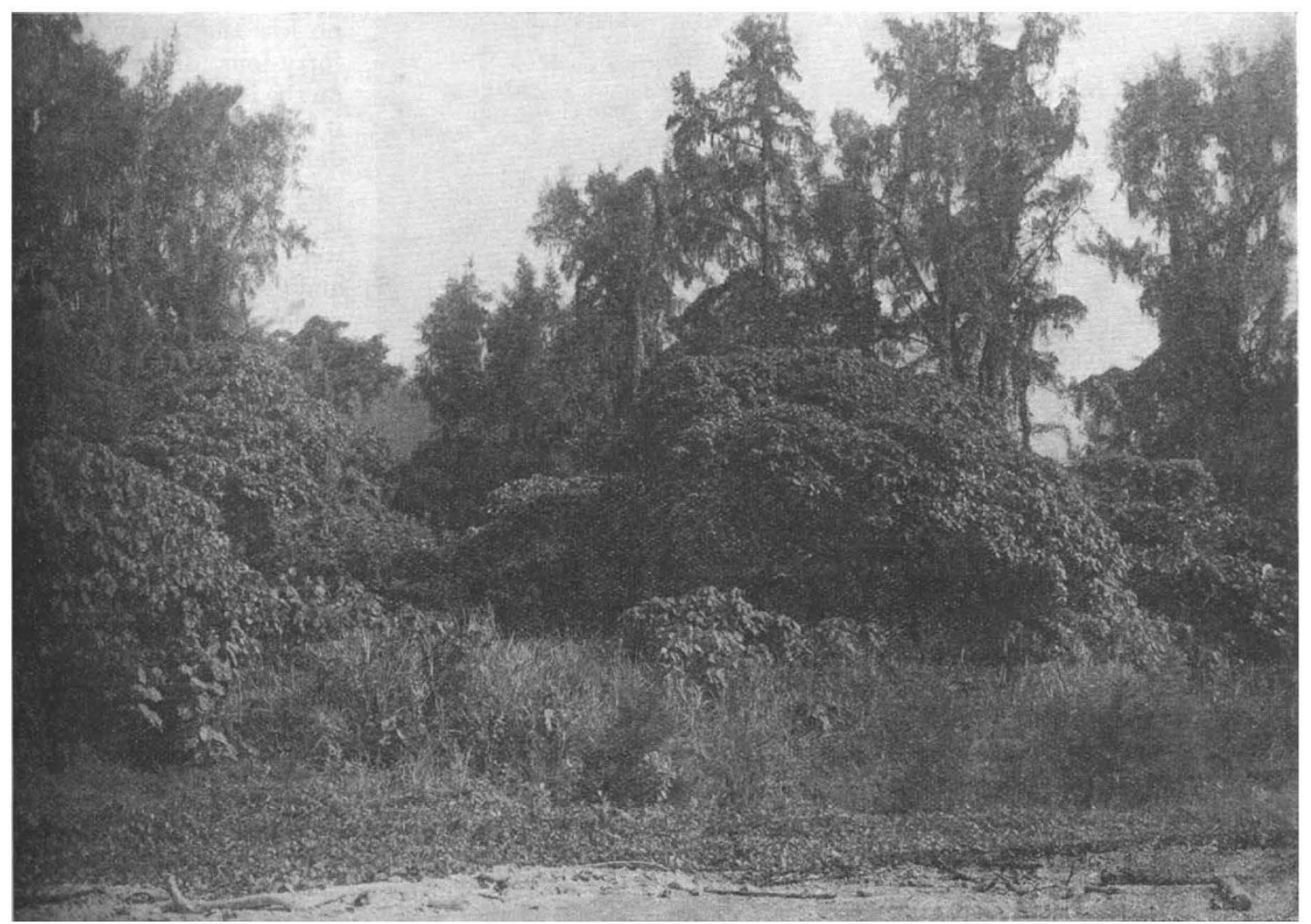

Fig. 3.

Krakatau, south-east side, May 1928.

seems clear that had any seeds remained viable after the eruption, such as those of Ficus fistulosa, $F$. hispida, F. toxicaria, Macaranga Tanarius, or even of Cycas Rumphii-the two Ficus first recorded in 1897, the rest in 1905-the seedlings would have been so tall in 1886 (several metres in the case of the first four, judging by observations made on their growth in Sumatra) that Treub could not have failed to have noticed them!

I fully agree therefore with Dr. Docters van Leeuwen, after carefully reading his able review of all the evidence, that not a single valid argument has been given that any part of the original vegetation of Krakatau was saved, and that the all dealt with in detail in the final chapters, which occupy 175 pages replete with valuable information. Chapter xvi deals with the means of transport by which the plants must have reached Krakatau - wind, sea, animals and man. Only the conclusions can be given here, but the discussion should be read in detail. Dr. Docters van Leeuwen feels justified in assuming that about 41 per cent of the plants now found in Krakatau (not counting the lower cryptogams), were transported by wind, 28 per cent were introduced by ocean eurrents, 25 per cent by animals, while not more than ten or fifteen plants, if as many, which may have been introduced by man, have survived. 
An interesting chapter (xviii) is devoted to the recently erupted island of Anak Krakatau, which first emerged above sea-level on January 26, 1928, and a list of the seeds and plants found on this 'baby' island by the author includes many coconuts, forty-one of which had germinated. These

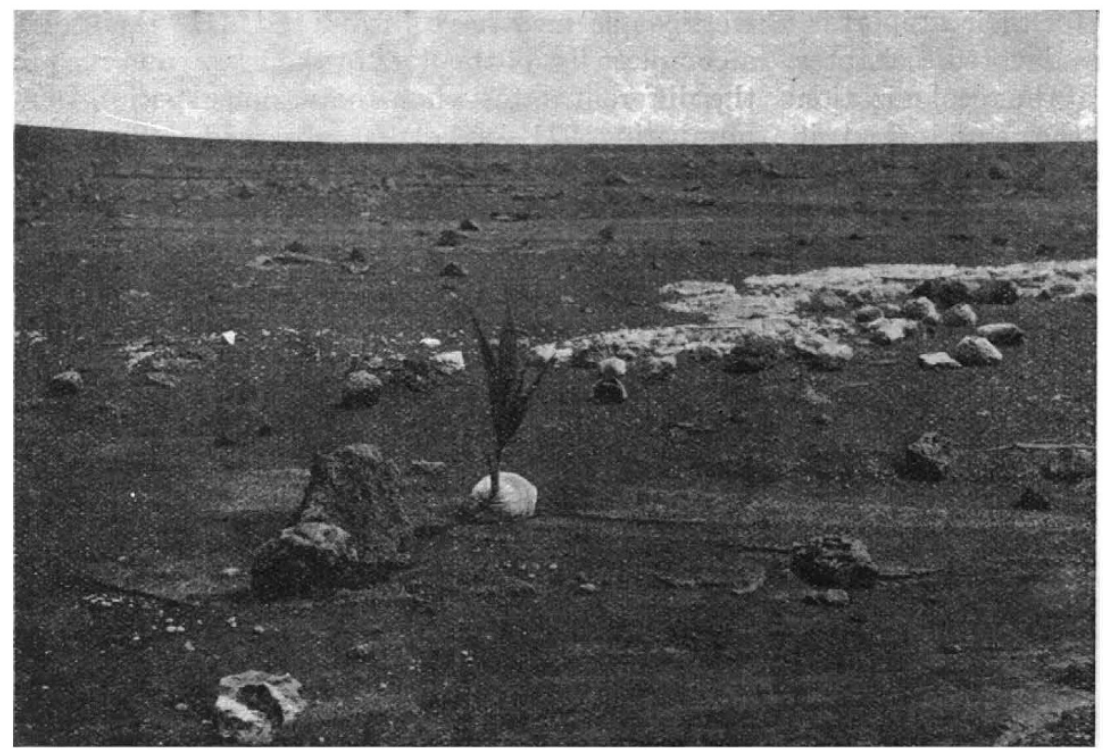

Fig. 4.

Anak Krakatau, May 1932. Photo by C. C. Reijnvaan.

no doubt will be destroyed during the next eruption, but the colonization of this new creation affords possibilities of a very interesting study.

Dr. Docters van Leeuwen's chapter (xxi) on Zoocecidia is one of the most valuable in the book, not only because he is a leading authority on the group, but also because these short-lived gallproducing insects and mites must have been destroyed by the eruption, so that all those now present on the island can only be immigrants.

No galls were found on the plants collected by Treub, though this does not prove that none had then arrived, but it is of interest that very few galls are known on the plants found by Treub on Krakatau in 1886. Dr. Docters van Leeuwen has collected no less than sixty galls on forty-four different plants on the islands. Since, then, it is inconceivable that these delicate insects can have survived the eruption, it is clear that the plants were the first immigrants, and when they had become established the gallproducers followed, being transported by the wind or ocean currents.

The value of the work is completed by the excellent bibliography and full index, and by the admirable illustrations, sixty-one in num. ber, showing various stages in the development of the vegetation on the islands.

Dr. Docters van Leeuwen has earned our grateful thanks for this convincing treatise-so well written in English-which he has most fittingly dedicated to the memory of Melchior Treub.
ARthur W. HIrL.

\section{Prevention of Smoke and Dust Emission from Chimneys}

$\mathrm{T}$ HE weight of coal consumed annually in Great Britain is approximately $\mathbf{1 6 5}$ million tons, and of this only a small proportion is burned without smoke or grit being discharged into the atmosphere. It is, however, not possible to make even an approximate estimate of the extent to which the use of coal is responsible for atmospheric pollution and its attendant evils, on account of the wide differences which occur in the nature and quantity of smoke or grit produced by the combustion of unit weight of fuel. Both depend upon the type of coal used, the purpose for which it is burned and the skill employed in burning it, all of which vary from case to case.
When coal is burned on a domestic grate-and some 35 million tons are used annually for household purposes-the smoke produced consists of partially cracked tarry vapours formed by the distillation of a portion of the volatile matter in the coal. The quantity depends, of course, upon the type of grate and the nature of the fuel used. To burn soft bituminous coal smokelessly in an open fireplace is extremely difficult, but endeavours are being made to devise a suitable grate. Should they not be successful, it will be necessary, if smoke is to be avoided, either to abandon the open fireplace altogether, or to increase still further the use of smokeless 